\title{
ヴォリュームの配列からみた複合建築の構成における統合形式 ARCHITECTURAL COMPOSITION OF COMPLEX BUILDINGS BY ARRANGEMENT OF VOLUMES
}

\author{
美濃部 幸郎*，坂 本一成**，塚 本 由 晴*** \\ Yukio MINOBE, Kazunari SAKAMOTO and Yoshiharu TSUKAMOTO
}

\begin{abstract}
This paper's aim is to clarify the characteristics of integrational form in spatial composition by analyzing typologically Japanese contemporary complex buildings as groups of volumes with arrangement.

Initially, the groups of volumes are defined by combination of the direction of arrangement and the element representing the bodies, and also several hierarchy-patterns are defined by the exerted ranges of those arrangements. Secondly, typological compositions are found by analyzing contents of the arrangements in the hierarchy-patterns.

Finally, through comparing those compositions, the integrational form is structured with the functions of arrangement that generate the relationships among volumes such as "master-servant".
\end{abstract}

Keywords: complex building, intergrational form, volume, arrangement, typology

複合建築、統合形式、ヴォリューム、配列、構成類型

\section{1. 序}

\section{1 複合建築と建築の統合形式}

資本や人口の集中した現代の都市において、従来の単一用途の 建物ではない、複数の用途が集合した複合建築が、多く建設さ れ、また多くの建築家がその設計に携わってきている。近年の再 開発事業によく見られた商業施設とホテル・住宅が一体となった 建物や、鉄道駅舎と商業施設・事務所建築が一体化したいわゆる 駅ビルなどは、そうした複合建築の例であるが、基本的にそれら は、狭小な土地に建造物が近接・集積した現代の高密な都市環境 において、用途の再編を通して、施設や設備を共用化し、土地や 施設等を高度利用するという、現代都市の功利的側面を体現する ものといえる。また一方、複合建築は、例えば従来は別々の建物 として分けられてきた劇場と美術館という異種用途が隣り合うこ とによって、ホワイエとギャラリーが融合するといった、それぞ れの用途が単独である場合とは異なるものとなるような、相乗的 な効果が生じる契機があると言える。こうした効果は資本等の功 利的運用やただ単に用途を複数化することだけではなく、異なる 用途を内包した空間をどのように隣接させるかという、部分相互 の構成によって成立していると考えられる。さらに、例えば劇場 を含む複合建築において、既成の劇場がそのまま、複合建築とい
う新たな全体の中での部分として構成されるだけであれば、単一 用途を中心として考えられてきた既成のビルディング・タイプを 単に集積した全体が形成されるというように、部分の構成は同時 に全体構成の問題でもある。このように異種用途が隣り合う複合 建築においては、部分相互の関係や部分と全体の関係を与える構 成の水準が、新たに再検討されるべき領域として浮上していると 考えられる。本研究はこうした問題意識のもとに、複合建築の全 体性を、空間構成の部分と全体の関係から問題とするものであ る。

近年大規模化の傾向にある複合建築の多くは、建物全体が外形 において分節された複数のヴォリュームから形成されている。そ してそれらのヴォリュームの集積によって、ヴォリュームに囲ま れた中庭を形成するものや、ヴォリュームを基壇状の低層部に重 層するもの、アトリウムを伴った長大なモールによってヴォ リュームを連結するものなど、何らかの秩序の見られる配列に よって、相対的に図として認識されるヴォリュームのまとまりを 形成するものも多く見られる。後に詳述するように、こうした秩 序ある配列による、図をなすヴォリュームのまとまりの形成を、 本論では「統合」りと定義するが、このような統合の在り方はそれ 自身、個別の建築作品の特徽を形成するばかりでなく、同様な構

Graduate Student, Tokyo Institute of Technology, M. Eng.

Prof., Dept. of Architecture, Faculty of Engineering, Tokyo Institute of Technology, Dr. Eng.

Lecturer, Dept. of Architecture, Faculty of Engineering, Tokyo Institute of Technology, Dr. Eng. 
成も多々見られることから、個々の事例を越えた類型として成立 していると見ることができる。そして類型を抽出することを通し て、それらを一貫した体系を持った形式として捉えることができ れば、建築の統合の在り方を、個別の与条件との対応による特殊 解であることを越えた、建築の形式一般の問題として捉えること が可能となる。さらにそのような統合形式を、具体的な要素を構 成する諸操作の関係として体系づけることができれば、既成の統 合形式に対して、構造的な分析と具体的な方法を伴った提案を行 うことも可能となると考える。

以上のことから本研究は、特に建築家は構成の問題を主として 思考していると考えられることから、建築家によって設計された 現代の複合建築を対象に、実体の構成分析を通して、建築の構成 における統合の形式を構造的な側面から明らかにすることを目的 としている。

\section{2 既往研究および本研究の意義}

本研究は建築の構成を構成要素の統合を通して検討するもので あり、このことは具体的には建築を部分と全体の関係から捉える ことと言える。こうした建築の構成における部分／全体の関係に 着目した既往の学術的な研究には、形式言語を用いて空間構成の 記述・分析方法を提案するもの 2)、空間を秩序づける外在的要因 のひとつとして祭儀や地域社会の習慣を捉え、それらとの相関に おいて建築の平面構成を検討するもの3、集合住宅や大学キャン パスを対象として、複数の建物による建築群の視覚的な特性や心 理的影響を分析するもの 4)、特定の建築書から構成要素の部分と

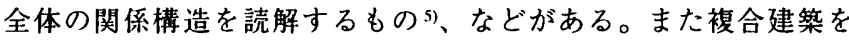
对象とした研究には、施設複合化計画の確立を目的として特に教 育施設を対象に、施設間の機能・管理運営の連携に関寸る現行調 查を行ったものの、店舖付集合住宅を対象に、動線と居住環境に 対する满足度の相関を調査したもの》、などがある。これら既往 の研究に対して、本研究は複数の建築家による現代の複合建築を 対象にした実体の構成分析を通して、断片的に捉えられる個々の 建築の構成的特徽を、構成要素の統合を通して構造的に捉えるこ とを目的にしており、このような視点はこれまでの学術的な研究 には見られない。

\section{3 研究の概要}

本研究では複合建築の構成を、分節された部分とそれらの統合 された全体の関係において捉えている。この分節された部分、つ まり構成における単位によって、構成の体系は規定される。1.1 で述べたとおり本研究が対象とする複合建築の多くは、その規模 が大きく、複雑な外形をなしている。このような建物の外形にお

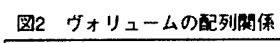

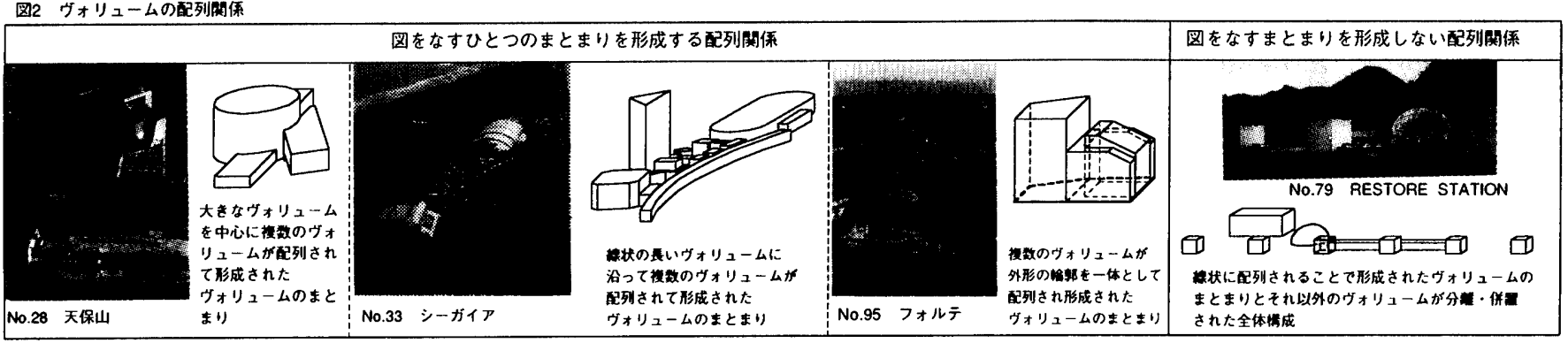

ける構成を捉えるには、建物の表層を分

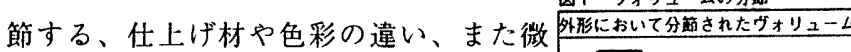
細な四凸に上る上りむ、3 次元的な空間 の広がりが物理的に規定された空間的な 単位によることが有効であると考える。 そこで本論では図1に示すように、3次 元的な広がりをもつ空間相互の違いを物

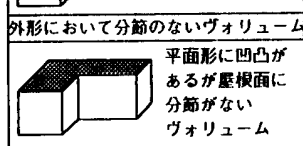
理的に示す、屋根面の分節に着目し、屋根面において分節された 単純な形態を有したヴォリューム(以下、ヴォリューム)を構成単

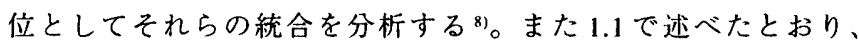
個々のヴォリュームはそれらが単に集合することで建物全体を構 成するだけでなく、図 2 の例に見られるように、秩序ある配列を 伴って図とみなせるまとまりを形成するものが見られる。さら に、そうした配列関係が建物総体において介在する範囲は、部分 的なものもあれば全体的となるものもある。こうしたまとまりを 形成する配列の内容やそれが介在する範囲は、それ以外の可能な 配列の中から選択された、構成単位の統合についての任意の表現 と見なすことができる。

そこで本研究では現代の襩合建築を対象に、外形で分節された ヴォリュームを構成単位として、それらがいかなる配列によって まとめられているか、またその配列関係が建物全体において部分 的か全体に及ぶかを分析することによって構成類型を導くと共 に、それら類型間に共通した性格を検討することで、建築の統合 形式における構造的な側面を明らかにしている》。そのため本研 究では個々の建築家の作品に見られる作家的特徴を越えた、ヴォ リュームの統合による建築の構成に内在する構造を問題とし、複 数の建築家による建物を並列的に比較検討している。分析資料と しては、現代の建築ジャーナリズムのなかで代表的なもののひと つと思われる「新建築」誌において、1990～96年に揭載された複 合建築 ${ }^{(0)} 106$ 個を対象としている(文末表 2 )。

\section{2. ヴォリュームの統合と階局性}

\section{1 ヴォリュームの統合}

1.3 で述べたように、本論では建築の統合形式を捉えるために、 外形に扔いて分節された少ォリュームを構成単位として、この単 位の配列関係から建物全体の構成を検討する。こうしたヴオ リュームの配列関係から統合形式を検討するためには、いかなる 配列関係を統合関係と捉えるかが問題となる。実例を検討すると これらヴォリュームの配列関係には図 2 の例に示すように、複数 のヴォリュームが外形の輪郭を一体として結合するなど、何らか の秩序の見られる配列によって相対的に図として認識されるひと 
つのまとまりを形成するものと、単なる隣接関係や分離した配列 関係にあって、ひとつのまとまりとはとれない配列関係にあるも のという違いを見ることができる。こうした明確な配列の秩序を 伴って形成されたヴォリュームのまとまりは、構成単位の統合に ついての任意の表現として見なすことができる。そこで本論では このような図をなす配列関係を統合関係として捉え、統合関係に あるヴォリュームのまとまりを特に「複合染ォリューム」と呼んで いる。また図をなす配列の形態的な特徴は様々あるが、図 2 の左 側 3 例に示すように、势りュームが求心的に配列されるか、線 状に配列されるか、外側への広がりを規定されて配列されるか、 というように配列の秩序の方向性の違いから大枠とらえることが できる。そこで複合ヴォリューム」を形成する配列の具体的な内 容を、こうした方向性から捉之(図 4 横軸)、それぞれの配列の内 容を「中心・対称性」(図 4 の記号 : $\mathrm{CvM} \cdot \mathrm{Cvm} \cdot \mathrm{Ce} \cdot \mathrm{S} \cdot \mathrm{C}$ )、「軸」( $\mathrm{Av} \cdot$ A)、「外形輪郭」 $(\mathrm{Fv} \cdot \mathrm{Fe} \cdot \mathrm{F})$ と呼んでいる。例えば図 2 の最も左の 例は相対的に大きなヴォリュームを中心として他のヴォリューム が結合されており、「中心・対称性」という配列によって形成され た「複合ヴォリューム」CvMを示す例である。

さらにこれらの「複合ヴォリューム」を検討すると、それを形成 する配列の内容を代表する特定の要素のあるものと、そのような 特定の要素がないものが見られる。例えば図 3 は同じ「外形輪郭」 という配列によって形成された「複合ヴォリューム」を示すが、一 方は平面的に他より大きなヴォリュームの上に小さなヴォリュー ムが積層されたもので、他方は複数のヴォリュームの結合によっ て一体となった外形の輪郭を形成するものである。これらを比較 図3統合子の有無による椱合ヴォリュームの差異

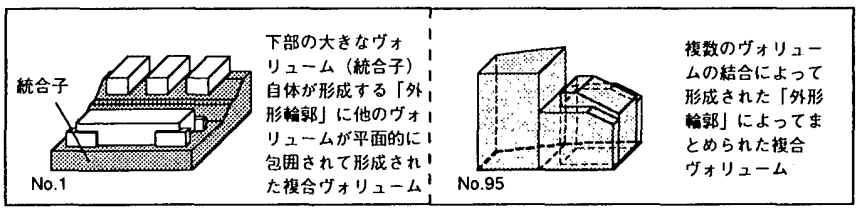

图 4 複合ヴォリュームの種類

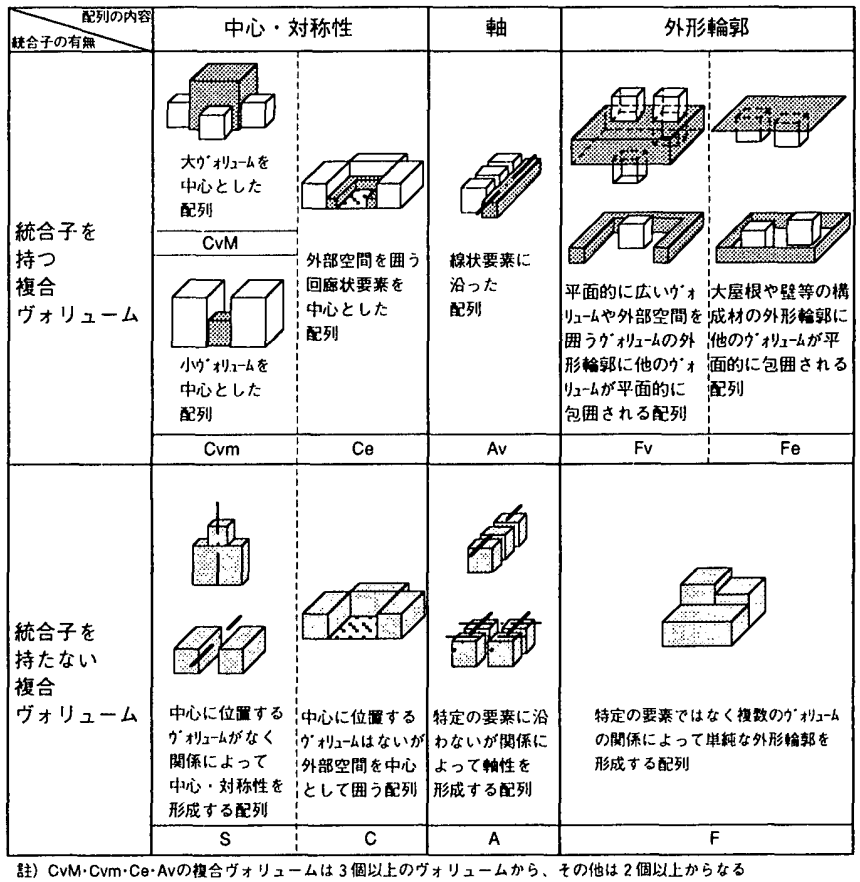

すると、前者は下部の大きなヴォリューム自体が形成する「外形 輪郭」に他のヴォリュームが平面的に包囲される関係にあるのに 対して、後者は「外形輪郭」が複数のヴォリュームのまとまりに よって形成されるという違いが見られる。前者のように、ヴォ リュームを統合する配列の内容を実体化した要素のことを特に 「統合子」と呼ぶと、両者の差異は、台や覆いのように他のヴォ リュームをまとめる「統合子」を持つ「複合少ォリューム」と、配列 関係だけでまとめられた「統合子」を持たない「複合ヴォリューム」 というように、「統合子」の有無として捉えられる。以上のことか ら、「統合子」の有無、また「統合子」がヴォリュームであるか大屋 根のような構成材であるかという違いと、前述した複合ヴォ リュームを形成する「中心・対称性」「軸」「外形輪郭」という配列の 内容の組合せとして、複合ヴオリュームの種類が図 4 のようにま とめられる。このことから例えば同じ「中心・対称性」という配列 によって形成された「複合ヴォリューム」でも、ヴォリュームを中 心とした配列は統合子を持つもの、中心にヴォリュームが無く外 部空間を中心として囲う配列は統合子を持たないものという違い として区別される。

\section{2 建築の階層的構成}

前節で定義した複合ヴォリュームによって建築の構成を検討す ると、複合ヴォリュームが部分的に形成され、さらにその部分的 なまとまりが建物全体を構成する、構成に階層のあるものや、 ヴォリュームがそのまま建物全体を構成する、構成に階層のない ものが見られる。例えば分析例(図 5 )は構成に階層のあるものの 图 5 分析例

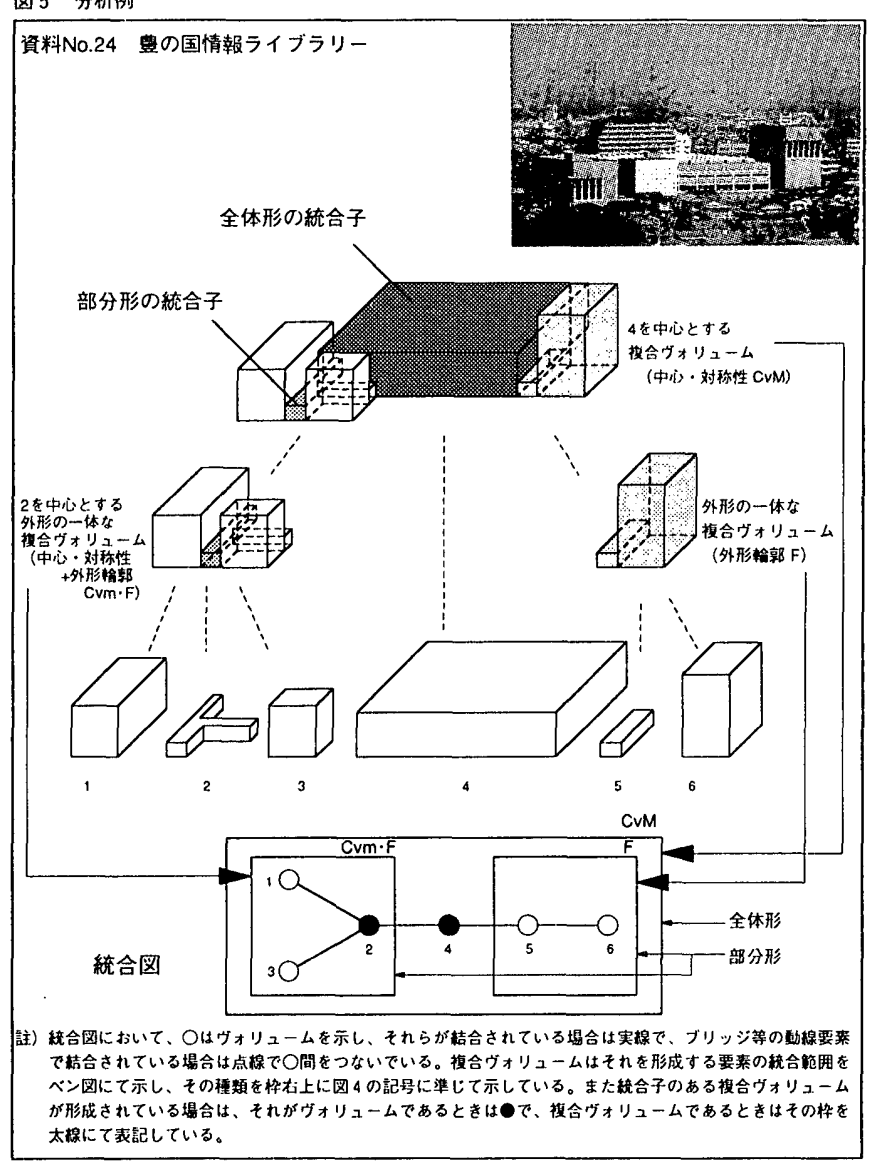




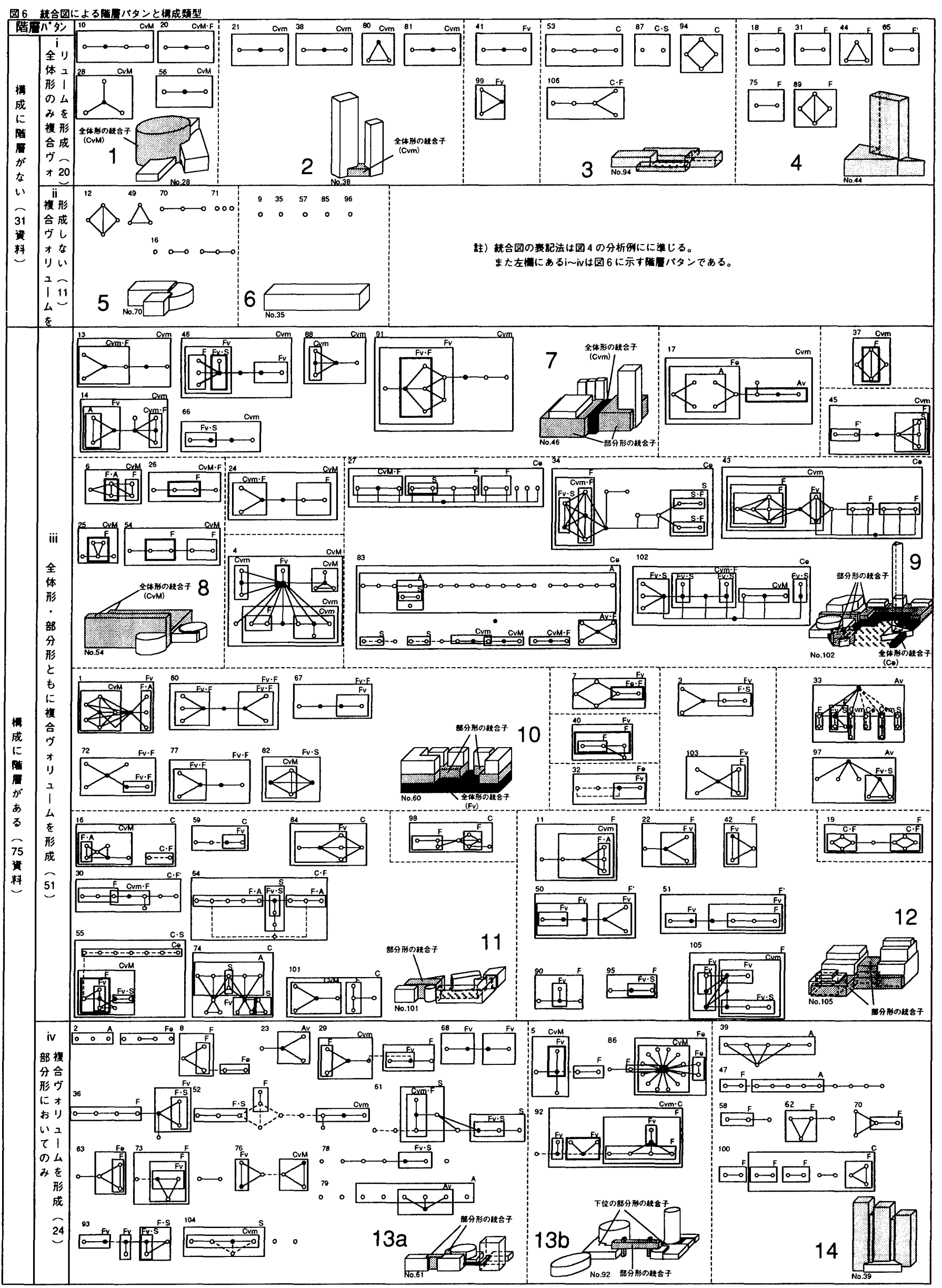




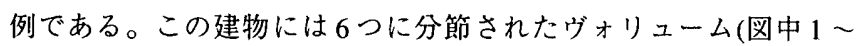
6番)があり、そのうち2番のヴォリュームを中心として複数の ヴォリュームが「中心・対称性」(Cvm)・「外形輪郭」(F)という配列 によって、5番と6 番のヴォリュームが「外形輪郭」(F)という配 列によって部分的な複合ヴォリュームとなり、更にこれら2つの

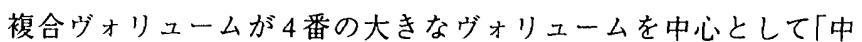
心・対称性」(CvM) という配列によって複合ヴォリュームとなる ことで、建物全体が構成されている。このように構成に階層が形 成される・されないということは、構成単位の統合が建物全体に 占める範囲の違いから生じることから、前節の複合ヴォリューム の種類と同様に、構成単位の統合についての任意の表現として捉 えることができる。こうした構成の階層は、建物全体を「全体 形」、部分的に形成された複合ヴォリュームを「部分形」とすると、 図 5 の分析例に示すように、ヴォリュームどうしが結合している か否かを示すグラフに加えて、全体形・部分形それぞれの複合 ヴォリュームを構成する要素の統合範囲を示したベン図(以下、 統合図)を用いることによって、平面的に図示することができる。 例えば分析例では、2つの部分形と1つのヴォリュームが全体形 の構成要素となっており、それらが全体形においても複合ヴォ リュームを形成することが、ベン図の包含関係として図示され る。

部分形と全体形の階層関係を調べるために、この表記法によっ て全資料を図示した(図 6 )。こ机らの統合図は、構成における階 層の有無を示寸部分形の形成の有無と、建物全体の統合的特徵を 示す全体形での複合ヴォリュームの形成の有無によって、図 7 に 示す論理的に可能な 4 種類の型(以下、階層パタン)として整理で きる。これらは i : 部分形を形成せず、全体形が複合ヴォリュー ムとなるもの $(20 / 106$ 資料)、ii：部分形を形成せず、全体形が複 合ヴォリュームではないもの(11/106)、iii：部分形を形成し、全 体形が複合り゙リュームとなるもの(51／106)、iv：部分形を形 成し、全体形が複合ヴォリュームではないもの(24/106)である。

\begin{tabular}{|c|c|c|}
\hline 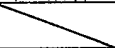 & $\begin{array}{l}\text { 全体形で襀合ウォリューム } \\
\text { を形成する (71) }\end{array}$ & $\begin{array}{l}\text { 全体形で裸合ヴォリューム } \\
\text { を形成しない(35) }\end{array}$ \\
\hline $\begin{array}{l}\text { 部分形 } \\
\text { を形成しない } \\
\text { (31) }\end{array}$ & 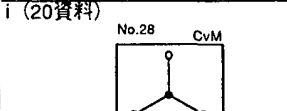 & ii (11算料) \\
\hline $\begin{array}{l}\text { 部分形 } \\
\text { を形成する } \\
\text { (75) }\end{array}$ & iii (51資料) & 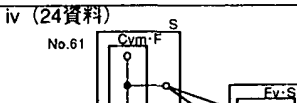 \\
\hline
\end{tabular}

表 1複合ヴリュームの種類と組合せ

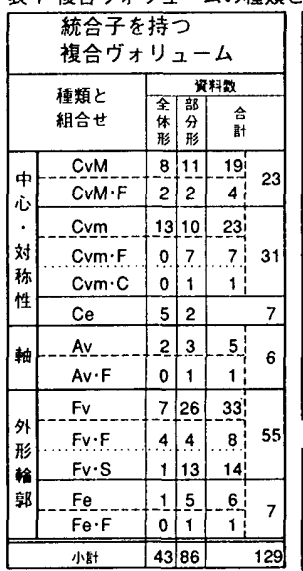

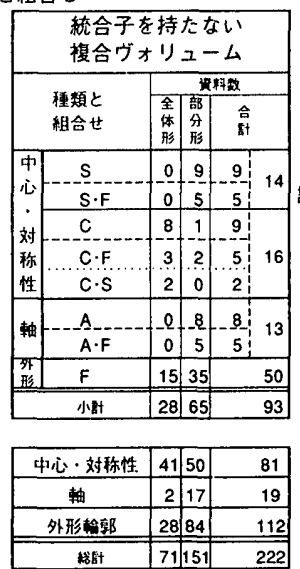

資料の中ではこれら階層パタンのうち、全体形が複合ヴォリュー ムとなり建物全体が統合された i ・ii(計 $71 / 106)$ が、建物全体が

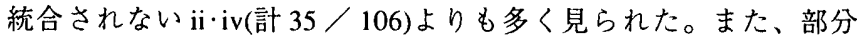
形を形成し構成を階層化する iii·iv(計 $75 / 106)$ が、構成が階層化 されない i ·ii(計 $31 ／ 106)$ よりも多く見られた。さらに傾向とし て、構成を階層化する iii·ivは、階層化しない i · ii よりも、多く のヴォリュームからなる ${ }^{22)}$ このことから階層的構成は、ヴオ リュームを多く分節しながらも部分的なまとまりをなすことに よって、全体形を見掛け上少ない要素によって構成するものと言 える。しかし、ヴォリューム数が多くとも構成を階層化しない、 逆にヴォリューム数が少なくとも構成を階層化する資料も見られ る。よって階層的構成は必ずしも建物の外形を多く分節する構成 ではなく、ヴォリュームの配列関係によって全体形とは異なるま とまりを部分的になす構成と言える。

さらに前節で定義した複合ヴォリュームの種類について全資料 を検討すると(表 1)、全体形においては全体形が複合ヴォリュー ムとなる資料(全 71 資料)中、「中心・対称性」によるものが約 6 割 (41／71)を占め、特に小ヴォリュームを中心とした Cvm、中庭を 中心としたCが多く見られた。また部分形(全151 個)の中では「外 形輪郭」によるものが約 6 割 $(84 / 151)$ と最も多く見られた。これ

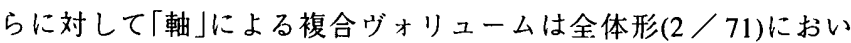
ても部分形 $(17 / 151)$ においても、他の配列の内容に比較して稀 なものであった。また「中心・対称性」「外形輪郭」の中でも、回廊 を中心とした Ceや、面材が外形のまとまりを形成する $\mathrm{Fe}$ も同様 に、数少ないものであった。更にほとんどの配列が全体形・部分 形のどちらかに偏っていないのに対して、CeやCは全体形に、対 称性を形成する $\mathrm{S}$ や軸性を形成する A は部分形に、偏って用いら れる傾向にあった。最後に複合ヴォリュームが統合子を含むか否 かについて見ると、統合子をもつ複合哭オリューム(129個)が持 たないもの(93 個)よりも多く見られ、この傾问は全体形(統合子 有 43 個／無 28)、部分形 $(86 / 65)$ に共通したものであった。

\section{3. ヴォリュームの配列による搆成類型と統合形式 3.1 構成類型}

前章では、ヴォリュームの配列関係による統合関係が、まとま りを形成する「中心・対称性、「軸」「外形輪郭」といった配列の内容 と、この内谷を実体化した要素である「統合子」の有無からなるこ とを示した。さらに統合関係をなすヴォリュームのまとまりであ る複合ヴォリュームが形成される範囲が、部分的か全体的かを検 討することによって、構成の階層的特徴を示す $\mathrm{i} \sim \mathrm{iv}$ の階層パ タンを導いた。本章では、こうした複合染ォリュームの種類と構 成の階層的特徽が、重なって形成される個々の建築の全体像を問 題とするために、階層パタンを軸に、全体形・部分形における複 合ヴォリュームの種類を重权て検討することによって ${ }^{13)}$ 、共通し た性格をもち頻度の高い資料のまとまりを1〜14の構成類型と して抽出した (図 6 )。

部分形を形成せず構成に階層がない階層パタン i・ii のうち、全 体形が複合少ォリュームとなる階層パタン $\mathrm{i}$ からは、その複合 ヴォリュームの種類から、「中心・対称性」のうち大きなヴォ 
リュームを中心に複数の小さなヴォリュームが統合(複合ヴォ リュームの種類 : CvM)された類型 1、それとは逆に小さなヴォ リュームを中心に複数の大きなヴォリュームが統合 $(\mathrm{Cv} \mathrm{m})$ された 類型 2、ヴォリュームではなく外部空間を、複数のヴォリューム によって包囲することで中心性を形成 $(\mathrm{C})$ する類型 3、また「外形 輪郭」のうち、複数のヴォリュームが輪部を一体として結合 $(\mathrm{F}) し$ た類型 4 が得られた。また構成に階層がなく、複合ヴォリューム も形成しない階層パタン ii からは、複数のヴォリュームが単に結 合、あるいは分離された類型 5、ヴォリュームが外形では分節さ れない類型 6 が得られた。

これらの類型に対して、類型 7〜 14 は部分形を形成すること で構成に階層のある階層パタンのものであり、そのうち類型 7 12 は全体形が複合ヴォリュームとなる階層パタン iiiに、類型 13. 14 は部分形においてのみ複合ヴォリュームを形成する階層パ夕 ン iv に属する。また階層パタン iii に属する類型 7 - 12 は、その 部分形の可能性として、統合子の有無による大枠 2 通りがある が、類型 8 を除く全ての類型が、統合子のある部分形を含む。こ うした部分形やヴォリュームが、類型 7 では単独の小さなヴォ リュームを中心 $(\mathrm{Cv} \mathrm{m})$ として、類型 8 は部分において「外形輪郭」 (F)によって形成された複合ヴォリュームが、全体においては最 大要素となり、これが中心となって統合(CvM)し、類型 9 では外 部空間を囲んだ回廊状要素によって統合 $(\mathrm{Ce})$ され、類型 10 では

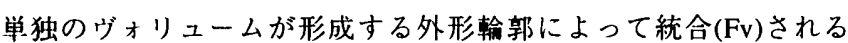
ものである。以上の全体形が統合子によって統合される類型に対 して、類型 11.12 は部分形やヴォリュームが、類型 11 では外部
空間を囲むこと $(\mathrm{C})$ で、類型 12 では外形輪郭を一体 $(\mathrm{F})$ として、統 合されたものである。

階層パタンivに属する類型 $13 \cdot 14$ は共に部分形が全体形にお いて複合ヴォリュームを形成せず、単に結合されるか分離された もので、このうち類型 13 は、部分形が統合子によって形成され、 中でも類型 13b は部分形の構成要素にさらに統合子によって形成 された複合ヴォリュームを含むものである。これに対して類型 14 は、部分形に統合子がないものである。

\section{2 類型問に共通する構成の働き}

以上得られた各構成類型は、それぞれに個別の特徽を持つが、 複合ヴォリュームに注目して各類型を比較すると、全体形を袮合 ヴォリュームとして形成する、あるいは部分形を形成し構成を階 層化する、またそれら複合ヴォリュームを統合子によって形成す る、といった類型を越えた共通性が見られる。2.で述べたように 複合ヴォリュームをなすヴォリューム間には、ヴォリュームの分 節と配列という構成上の操作によって統合関係が与えられ、その ことが建物全体の特徴を形成するから、そうした関係を与えるこ とは、単に要素を配列するだけではない、相対的な関係の中で部 分や全体を性格づけるという、構成の働きを示すものと考えられ る。このように考えると、複合等ォリュームに関して共通性の見 られる各類型では、ヴォリュームの構成における同じ働きが選択 されていると言える。つまり各類型間の関係を、構成の働きの共 通性から捉えることによって、それぞれの類型の構成において、 可能性としてどのような構成となることが検討され、そのうち何

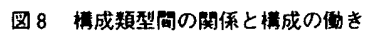

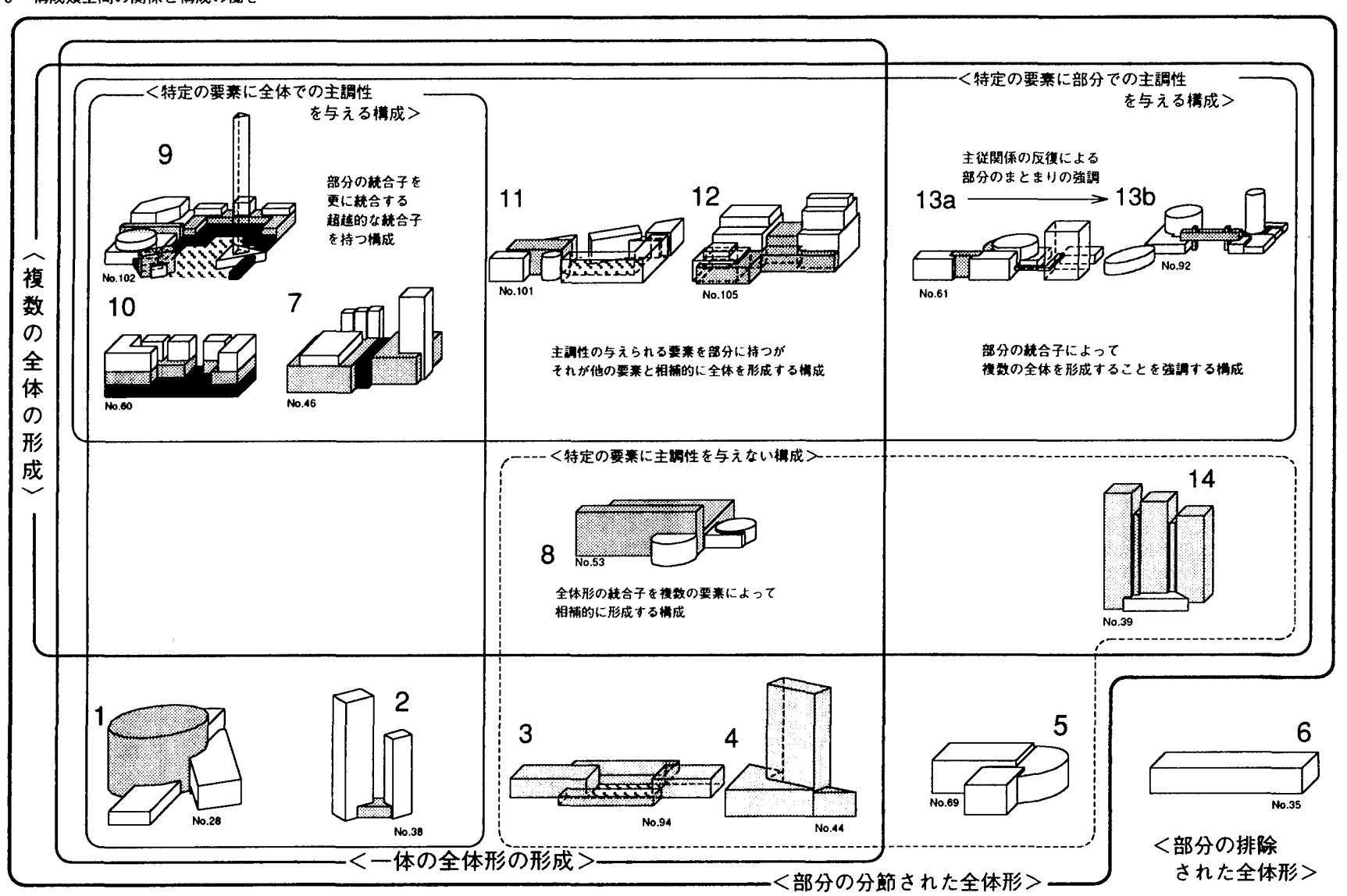


が選択されあるいは回避されているかという、実体の構成に潜在 的な、個別の特徴を越えた建築の形式の構造を浮き上がらせるこ とができる(図 8 )。

全類型のうち類型 6 以外の類型はヴォリュームを分節し、複数 の要素によって全体形を形成することで共通しているが、類型 6 はヴォリュームを分節せず、単独のヴォリュームがそのまま建築 の全体形となっている。部分／全体の関係や要素間の関係は、 ヴォリュームが分節されることで生じるが、類型 6 は要素の切り 分け自体をなくすことで、部分／全体や要素間の関係による構成 であることの可能性を回避すると考えるならば、<部分の排除さ れた全体形〉を形成するものと言える。逆に他の類型は、<部分 の分節された全体形 >を形成するものと捉えられる。このく部分 の分節された全体形>を形成する類型のうち、類型 1〜 4と 7 12 は全体形を複合ヴォリュームとして形成し、建築全体を相对 的に図として一体なものとして表現することから、く一体の全体 形の形成 >という構成の働きとして捉えられる。これに対して類 型 5.13.14 は全体形を複合ヴォリュームとしては形成しないこと によって、全体形を一体とする構成の可能性を回避して成立する 類型と言える。また類型 7〜14 は部分形を形成することで共通 している。この部分形が形成されるということを、建築には全体 形が必ずあるのに対して、部分的に一体となったまとまりを形成 することで全体形とは異なるまとまりを形成し、全体というもの を複数形成しようとすることと考えるならば、類型 7〜 14はく複 数の全体の形成 >という構成の働きとして捉えられる。これに対 して類型 1〜5は部分形を形成しないことによって、全体を複数 持つ可能性を回避していると言える。

次に統合子によって形成される複合ヴォリュームに注目する と、類型 $1 \cdot 2 \cdot 7 \cdot 9 \cdot 10$ は全体形が、複合化されない単一の要素が 統合子となる複合林オリュームであることで共通している。統合 子をその他の要素を「統合する」要素として捉えると、この複合 ヴォリュームでは要素間に統合関係が与えられると共に、「統合す る/される」という主従関係が形成され、統合子にはそのまとま りの中で主調性(ドミナント)が与えられると捉えられる。このよ うに考えれば先の類型はく特定の要素に全体での主調性を与える

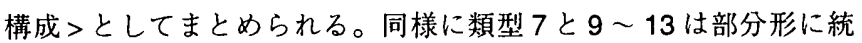
合子があることからく特定の要素に部分での主調性を与える構成 >としてまとめられる。このうち類型 7·9・10では両者が重なり、 部分形において主調性の与えられた要素が、全体形においては 「統合される」側として従属的な性格が与えられる。このように主 従関係が階層を横断して反復されることで、全体形における統合 子には全構成要素のなかで超越的とも言えるより支配的な性格 が、部分における「統合される」側の要素にはより従属的な性格が 与えられる構成として捉えられる。これに対して類型 13 は部分 で主調性を与えるが、く一体の全体形の形成〉がされず、全体形 で要素間に積極的な関係を与えることが回避されることによっ て、部分形における主従関係が顕在化し、《複数の全体の形成 > を強調するものと捉えられる。特に類型 13b は部分形を構成する 複合ヴォリュームにおいても更に主従関係が形成され、類型 7 . $9 \cdot 10$ のような主従関係の反復が部分形にあることから、類型 7 . $9 \cdot 10$ とは逆に部分のまとまりの存在が建築全体のなかで強調さ
れていると言える。また類型11.12 は 13 と同様に部分に主調性 の与えられた要素があるが、13 とは異なってく一体の全体形の 形成>を回避しないことから、部分では主調性の与えられた要素 が全体形においては他の要素と等価な性格が与えられ、それらが 相補的に全体を形成する構成と言える。以上の類型に対して、類 型 3·4·5·8·14は全体においても部分においても統合子が無いこ とで共通し、ある要素に主調性を与えることを回避していると考 えられることから、く特定の要素に主調性を与えない構成〉とし てまとめられる。このうち類型 8 は1·2·7·9・10に見られる全体 形の統合子を、複数の要素によって相補的に形成しており、全体 形における「統合する」という役割を分散させ、要素間の主従関係 を緩和する構成と言える。また類型 5 はヴォリュームを分節しな がら要素間に積極的な関係を与えないわけだが、これは、ここで 抽出された要素間の主従関係に関連した、全ての構成の働きが重 ねられることで、全体の中でより主調性の強調された統合子をも つ構成である類型 $7 \cdot 9 \cdot 10$ とは、対極的な性格を有した構成と言 える。

\section{4. 結論}

以上本研究では、現代日本の複合建築を資料としてその統合形 式を、外形で分節されるヴォリュームを構成単位として、それら 単位の配列関係から検討し、構成の階層的特徵を示す階層パ夕ン と、構成類型を導いた。さらにこれら類型を比較検討し、それぞ れに共通した、相対的な関係の中で部分や全体に性格を与える構 成の働きに着目することで、各類型を関係づける構造を明らかに した。この構造は、ヴォリュームの分節の有無によるく部分の分 節された全体形 > / <部分の排除された全体形 >、統合関係が建 築全体に及ぶく一体の全体形の形成 $>/$ 部分的に統合関係が与え られるく複数の全体の形成 >、また統合子の有無によって要素に 与えられる性格に関したく特定の要素に全体での主調性を与える 構成 $>$ 〈 特定の要素に部分での主調性を与える構成 $>/<$ 特定 の要素に主調性を与えない構成 >といった、範列的な構成の働き からなり、各類型はこれらの重なりとして捉えられた。そしてこ の構造から、建築全体の性格が特に、全体の中で超越的な性格を 与えられた要素によって統合された構成と、逆にヴォリュームが 分節されるだけで全体が統合されない構成を対極とした、多様な ものとなることを明らかにした。また多くの資料でヴォリューム が部分的に統合されていることから、現代日本の複合建築の構成 の多くは、ヴォリュームどうしを直接的に関係づけるよりは、部 分的にまとまりを形成することで階層化された全体構成をなして いることが明らかとなった。

ここで得られた結果は、ヴォリュームを構成単位とした建築の 統合形式に内在的な構造を示すと同時に、要素の相対的な性格や 建築全体の性格を、配列という具体的な操作によって定義する可 能性の一端を示すものと考える。本論では構成単位をり゙ォリュー ムに、また分析対象を建築単体に限定しその全体性を問題とした が、今後はヴォリュームの内部空間の統合について、また周辺環 境との相対的な関係における建築の全体性について検討する予定 である。 
註

1)公辞苑によ札ば、統介は・般に|2つ以にのものをひとつに統(す)べあわせるこ と」という意味で用いられれる。本論で用いる統合は、この意味にならいながら特 に、椱数の棈成要素が配列されることで、ひとまとまりの园として認識される関 係が形成されること、と、方意味で用いている。

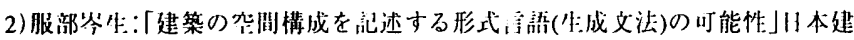

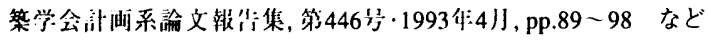

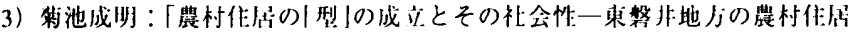

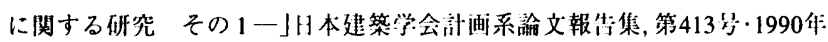

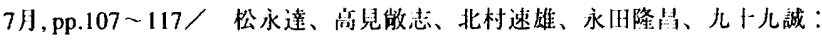

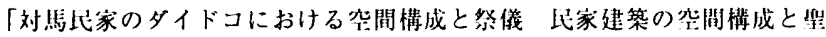

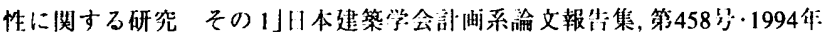
4月,pp.155〜162 など

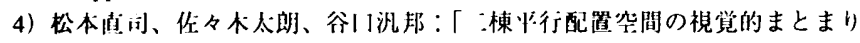

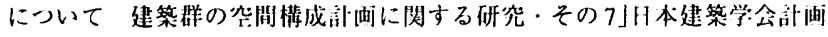

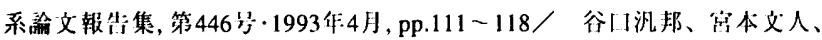
共野筧：「建築群が模成する明み空間の物理的特性と梘覚的意味について

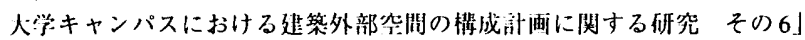

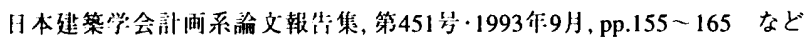

5）加藤道犬：「J.N.L. デュランのコンポジションに゙ついて」H本建箖学会部曲 系淪文報告集, 第440号・1992年:10月, pp.149－156/ 相川浩：「アルベルテ1

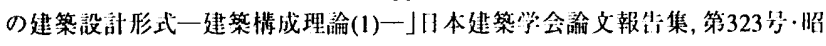
和 58 年1月,pp.116ー123 など

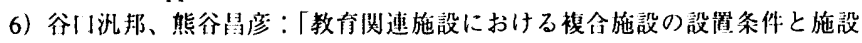

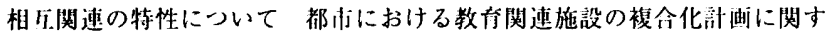

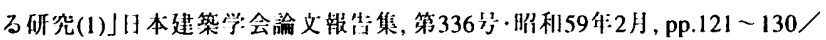

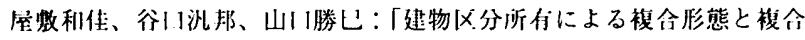

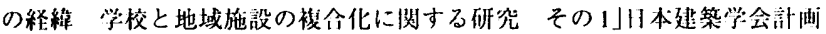
系論文報告集, 第452思・1993年10月, pp.65〜74 など

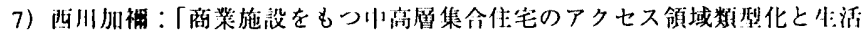

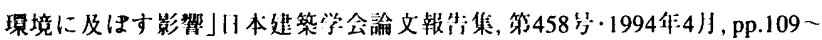
115 など

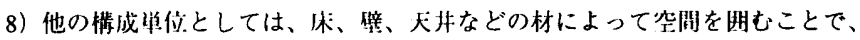

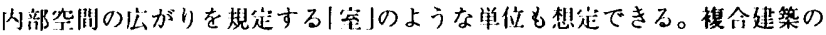

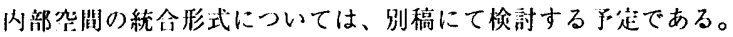

9）本研究は以下の拙稿を捈樹し、加筆・修正したものである。

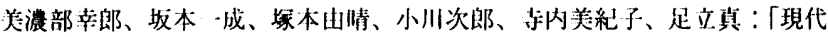
建筑の棈成における統令形式に関する研究(1)(2)」山本建筑学会大会学術講 演梗概集(関東), pp.269-272,1997 年 9 月

10）建筑大辞典(彰国社)によ机ば複合建築」は用途の是なる被数の建築の身 今体として造られる建築。ターミナルビル、下䭾塄きアパート、ショッピ ングセンター、都心のホテル・デパートなどがその例。と定義されている。

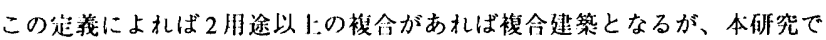
は資料の選定にあたり住宅业オフィスのような軽微な裸命を除くため、3

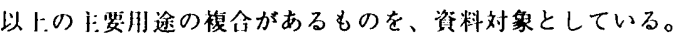

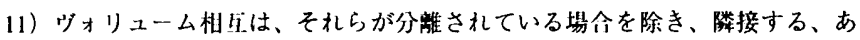
るいは皘牌するといった、文休的な結合関係にある。本論はこうした楛命 関係とは別に、图 4 にホすようなウォリュームのまとまりをなす配列関係

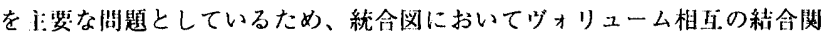
係は、その有無のみを線分で京し、トト主们といった具体的な位圆阅係や 遠近などの距耀関倸を捨象したグラフで四ふしている。

12）階单的構成の論理的な必紧条件は、听ォリューム数が 3 以上あることで ある。

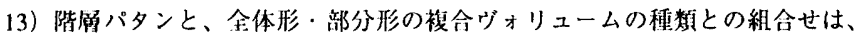
論理的にはひとつの建物に㧈ける部分形の数に制限は無いので、組合せの 総数は限定できない。本論は、建物の全体としての統合の在りうに特に注 Hし、部分形では統合子のの值無のみを、全体非において䙁合ヴリューム の)具体的な種類、また統命了がヴォリュームが褚合离ォリュームであるか を検尉しているため、淪理的に㞴能な組令せは何限個（総数 41 通り）で あり、このうち資料が相対的に多くまとまったものを数型として抽州して

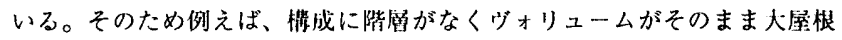
に統合さ扎た情成のように、諭理的には叮能であるが該当する资料のない 權成も見られた（15通り)。

\begin{tabular}{|c|c|c|}
\hline & & \\
\hline No. & 瓷料名称 & 年月 \\
\hline & 1)永島岍” & $\overline{9612}$ \\
\hline & 2) 久連子古代の里 & 9612 \\
\hline & 3|山口県国際総合センター & 9609 \\
\hline & 4 愛知県児童棇合センター & 9609 \\
\hline & 5 八多ふれあいせンー & 9606 \\
\hline & 6雄勝町総合文化会館 & 9606 \\
\hline & メテオプラ゙ 洲 & 9605 \\
\hline & 8喜岐文化ホール & 9604 \\
\hline & 9 Kid Museum & 9604 \\
\hline & 0森の中の星の見える末-ネ & 9604 \\
\hline & 1)大田区産業プラザ & 9603 \\
\hline & 2姫.工大書写紀念会館 & 9603 \\
\hline & 3|ワミエニティ・プラザ平野 & 9602 \\
\hline & 4|棚倉町文化センタ- & 9601 \\
\hline & 5|山梨フルーツミンージフム & 9601 \\
\hline & 6黑部市国際文化センター & 9601 \\
\hline & 7 欯ン温泉「Mコ236 & 9512 \\
\hline & 8下北沢Sビル & 9511 \\
\hline & 9江津市総合市民センター & 9509 \\
\hline & d福井県生活学習館 & 9508 \\
\hline 21 & 1|ぶれあい港館 & 9508 \\
\hline & 2)アクロス福岡 & 9507 \\
\hline & 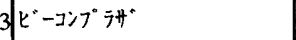 & 9507 \\
\hline & 4|豊の国情報ライ゙ラ゙リー & 9505 \\
\hline & 5|昭和町農村環境改善センタ一 & 9505 \\
\hline & 6下伽三田・和吅訪 & 9504 \\
\hline & 7直島町棇合福裃ぜター & 9504 \\
\hline
\end{tabular}

\begin{tabular}{|c|c|c|}
\hline No & 瓷料名称 & 揭戴 \\
\hline 28 & $\sqrt{\text { 天保山 }}$ & $\longdiv { 9 5 0 3 }$ \\
\hline & 那須野が原ハーモニ-ホーー & $\mid 9503$ \\
\hline 30 & 姫路市中央保健センタ- & 9503 \\
\hline 31 & ラ・ペルラ & $\mid 9503$ \\
\hline & すみだ生涯学習センター & $\mid 9501$ \\
\hline 33 & 汸ガイ & $\mid 9501$ \\
\hline 34 & 三重県総合文化センター & || 9412 \\
\hline 35 & 大島町絵本館 & $\mid 9411$ \\
\hline 36 & 西海パートシーセンター & 9410 \\
\hline 37 & いわきニュータウンセンターピ & 9410 \\
\hline 38 & 聖露加ガーデン & ||9409 \\
\hline 39 & 新宿パータタクー & $\mid$ || 9409 \\
\hline 40 & 基町クルド & || 9408 \\
\hline 41 & つくば献駐車場 & || 9406 \\
\hline 42 & 松葉ヒ’れ & || 9406 \\
\hline 43 & 足立区科学館·西新井末- $\lambda$ & $\mid$ || 9405 \\
\hline & 棁 $n$ 金沢 & $\mid 9405$ \\
\hline 45 & 會教市芸文館 & 9404 \\
\hline 46 & 月゙イイイタエよこすか & $\mid$ || 9404 \\
\hline 47 & 稗原コミュニテイスクール & 9404 \\
\hline 48 & 㭌質試行 $367^{*}$ ロジェタkk2 & 9403 \\
\hline 49 & ヴイドラセミナーハウス & 9402 \\
\hline 50 & 緑園都市AMNIS & 9401 \\
\hline & 緑園都市PRADO & 9401 \\
\hline 52 & 中世田谷ビジジススクエフ & 9312 \\
\hline 53 & 仆ツック仙台司教区センター & 9311 \\
\hline & 島根県立産業交流会館 & $\| 9311$ \\
\hline
\end{tabular}

\begin{tabular}{|c|c|c|}
\hline No. & 算料名称 & $\begin{array}{l}\text { 揭㖪 } \\
\text { 年月 }\end{array}$ \\
\hline$\overline{55}$ & 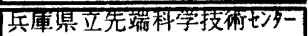 & $\overline{\overline{9310}}$ \\
\hline 56 & 北九州市立国際村交流センタ- & 9309 \\
\hline 57 & 芢么 & 9308 \\
\hline 58 & 横浜ランドマーク多- & 9308 \\
\hline 59 & 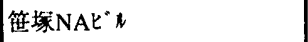 & 9307 \\
\hline 60 & 緑園都市OBERISK & 9306 \\
\hline 61 & けいはんなプラザ & 9306 \\
\hline 62 & 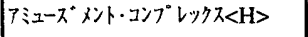 & 9304 \\
\hline 63 & JTBフォレスタ & 9303 \\
\hline 64 & 中主豊積の里総合センター & 9302 \\
\hline 65 & 路線脇のコンプレクス & 9302 \\
\hline 66 & $77^{\circ}$ ロ-ズタク- & 9301 \\
\hline 67 & PIANTE & 9212 \\
\hline 68 & 唯心館 & 9212 \\
\hline 69 & |宮沢賢治イーハトーブ館 & 9212 \\
\hline 70 & 東松山市総合会館 & 9211 \\
\hline 71 & 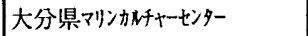 & 9210 \\
\hline 72 & XYSTUS & 9210 \\
\hline 73 & NBK関公園事務所掼·杖 $\boldsymbol{M}$ 棟 & 9210 \\
\hline 74 & |シーフォートスタエ & 9209 \\
\hline 75 & ロ・スフホンド & 9208 \\
\hline 76 & アクシス玄海 & 9207 \\
\hline 77 & 高島平の集合住宅 & 9205 \\
\hline 78 & 柏原タウンゼター & 9205 \\
\hline 79 & RESTORE STATION & 9204 \\
\hline 80 & 世田谷区松沢出張所 & 9204 \\
\hline 81 & M2 & 203 \\
\hline
\end{tabular}

\begin{tabular}{|c|c|c|}
\hline No. & 稘料名称 & $\begin{array}{l}\text { 摥戴 } \\
\end{array}$ \\
\hline 82 & 岡山シクォニー-木-n & $\overline{9201}$ \\
\hline 83 & 熊本県農業公園 & 9111 \\
\hline 84 & |大阪国際平和センタ- & 9111 \\
\hline 85 & $j \cdot 7 x=-f x$ & 9109 \\
\hline 86 & 古河スポーツ7オーラム & 9108 \\
\hline 87 & 자 $\bar{y}-\xi^{*}$ & 9107 \\
\hline 88 & 福野文化創造ゼター & 9106 \\
\hline 89 & 北沢哕冰-n & 9104 \\
\hline 90 & 北とびあ & 9104 \\
\hline 91 & 日立泌・ックセンター & 9104 \\
\hline 92 & 日本青年交流センタ- & 9103 \\
\hline 93 & 对馬豊玉町<文化の烺〉> & 9103 \\
\hline 94 & ふるさとの館 & 9102 \\
\hline 95 & TTAT & 9102 \\
\hline 96 & JOULE-A & 9102 \\
\hline 97 & 更埴市総合文化会館 & 9101 \\
\hline 98 & 北九州国際会議場 & 9012 \\
\hline 99 & 京つけもの西利 & 9011 \\
\hline 100 & 建部町国際交流館 & 9010 \\
\hline 101 & |秋田日産コンプレックス & 9009 \\
\hline 102 & 水戸芸術館 & 9007 \\
\hline 103 & 松下IMPt” ${ }^{\circ}$ & 9006 \\
\hline 104 & 菒張テクカガーデン & 9006 \\
\hline 105 & 富山市民プラザ & 9005 \\
\hline 106 & 相鉄文化会館 & 9003 \\
\hline
\end{tabular}

